\title{
Monografie otvírající nový prostor
}

\author{
Ivo Pospíšil (Brno)
}

Suttner im Kontext. Interdisziplinäre Beiträge zu Werk und Leben der Friedensnobelpreisträgerin. Herausgegeben von Johann Georg Lughofer, Milan Tvrdík unter Mitarbeit von Konstantin Kountouroyanis. Heidelberg: Universitätsverlag WINTER, 2017. ISBN 978-3-8253-6552-3.

Když se podíváme do katalogů evropských knihoven, lehce zjistíme, že obsahují desítky publikačních položek, které se týkají slavné ženy česko-rakouského původu označované různě, nejčastěji však jako Bertha Sophia Felicita von Suttner(ová), rozená hraběnka Kinská z Vchynic a Tetova (něm. von Wchinitz und Tettau, 1843 Praha - 1914 Vídeň); např. ve Vídeňské univerzitní knihovně najdeme přes 500 položek, v pražské Národní knihovně je to 53 položek. Je zjevné, že po vlně zájmu před první světovou válkou, později i v souvislosti s udělením Nobelovy ceny za mír (1905), kdy se autorčiny práce setkávaly se značnou pozorností, kdy vycházely její novely a román Odzbrojte! v německém originále a v překladech do několika jazyků (Die Waffen nieder, 1889, angl. Lay Down Your Arms, 1892, česky 1896), přichází nová vlna od devadesátých let 20. století s radikálně změněnou mezinárodní situací a také s řadou iluzí a s obnovou zájmu o autory tohoto typu, tedy stojící na rozhraní více jazyků a kultur, o problematiku gender studies, feminismus apod. Bertha von Suttner byla ženou mnoha profesí a bývá také pokládána za mezinárodní dobrodružku: cestovala po celé Evropě, pobývala v Gruzii, přednášela v hlavních evropských městech a v USA. V této souvislosti nemá smysl opakovat její životopisná data, i když i zde jsou bílá místa a fakta, která se různě interpretují. V každém př́ípadě jde o výjimečnou ženu, podle některých snad nejslavnější ženu před první světovou válkou vůbec, autorku románu a novel a aktivistku různých ženských a mírových organizací a hnutí, pacifistku, publicistku, cestovatelku, překladatelku, etnografku, která kromě němčiny a češtiny ovládala několik dalších jazyků, přeložila gruzínský hrdinský epos Hrdina v tygř́ kưżi Šoty Rustaveliho, psala prózy a publikovala již uvedený román Odzbrojte! Je zřejmé, že její činnost iniciovala nejprve situace osobní a existenční nejistoty, sňatek proti vůli rodičů manžela, styk s Alfredem Nobelem (byla to pravděpodobně ona, kdo inicioval vznik Nobelovy ceny, již také za pár let v roce 1905 sama dostala). Ale poté šlo spíše o impakt vzdělání a vlastní četby a uvažování a také evropské zkušenosti v situaci všeobecného zbrojení, jež nakonec vyústilo ve válku, jíž se však Bertha von Suttner již nedožila (zemřela osudného roku jejího počátku 21. 6., sarajevský atentát se odehrál 28. 6.). Je také zřejmé, že její pacifismus a odpor $\mathrm{k}$ válce vyrostl $\mathrm{z}$ tehdejších pacifistických tendencí, jež se staly tak trochu módou, stejně jako volnomyšlenkářství a s ním spojený ateismus, anarchismus, marxismus, mysticismus aj., jistě i pozapomenutá filozofie tolstojovství.

Autorský tým byl vytvořen ze znalců jejího díla, kteří však mají současně široký mezinárodní rozhled; většina studovala a přednášela v několika zemích a jsou zde tedy předpoklady srovnávací a hlubinně reflexivní. Multidisciplinarita/ interdisciplinarita je ostatně vložena do podtitulku přítomné publikace. Jednotliví autoři nastavují hrany díla Berthy von Suttner do různých stran, nahlížejí na její tvorbu z různých zorných úhlů. Madeleine Bernstorff (berlínská filmoložka a kurátorka) ve studii Film pro novou dobu? (Ein Film für die Neue Zeit? Ned med Vaabnene/Die Waffen nieder) píše o dánském zfilmování slavného románu v předvečer první světové války (režisér Holger-Madsen, scénář Carl Theodor Dreyer). Laurie R. Cohen (innsbrucká 
historička, studovala v Berkeley, New Havenu a Vídni), ukazuje ve své práci Berthu von Suttner jako činitelku mírového a ženského hnutí. Libuše Heczková a Olga Słowik (pražské literární historičky) poukazují na český kontext činnosti Berthy von Suttner, a to na čtveřici českých činitelek mírového hnutí - Vlastě Pittnerové (přeložila román Die Waffen nieder), Jindřišsce Wurmové, Pavle Moudré a Anně Pammrové, všech silně napojených na tehdejší českou kulturu a literaturu a její protagonisty. Viera Glosíková (pražská germanistika, původem ze Slovenska, znalkyně německé a české židovské literatury), v př́ispěvku Suttners Verhältnis zu den Tschechen aufgrund ihrer Memoiren ukazuje na autorčinu pozici mezi Čechy a Němci v německé literatuře a kultuře v tehdejších Čechách a na spojitosti s dramatem Karla Krause Die letzten Tage der Menschheit. Velmi zajímavý materiálově i koncepčně je příspěvek Dietmara Goltschnigga (germanista, odborník na novější německou literaturu ze Štýrského Hradce) o trojúhelníku Karl Kraus - Bertha von Suttner - Alice Therese Emma Schalek (1874-1956). Obě ženy byly dobrodružky, prosadily se v různých pozicích, Schalek byla fotografka a válečná zpravodajka a činitelka ženského a židovského hnutí (její činnost je však mnohem bohatší) terčem kritiky obou byl jejich aktivismus a naivita. Johann Georg Lughofer (germanista, historik, politolog a filozof) se dotýká právě těchto vlastností v literárním díle Berthy von Suttner, tedy naivity, sentimentality (Gartenlaube-Literatur $=$,literatura zahradního altánku“) a genderového aspektu její tvorby (pohlavní role). Mira Miladinović Zalaznik (slovinská germanistka a romanistka) zkoumá ve své studii cestu Berty von Suttner jako pacifistky. Alexandra Millner (rakouská germanistka, anglistka, literární vědkyně, kritička, dramaturgyně) a Katalin Teller (mad’arská germanistka a slavistka) demonstrují cestopisnou literaturu, kterou psala Bertha se svým manželem, jejich etnografické črty o pozici mezi exotikou a civilizací. Ulrike Tanzer (rakouská germanistka a anglistka a amerikanistka) komparuje Marii von Ebner-Eschenbach a Berthu von Suttner, téma, které není nové a přímo se nabízí, pojednala originálně a takřka vyčerpávajícím způsobem z vymezeného aspektu. Eveline Thalmann (germanistika a genre studies ve Štýrském Hradci) píše o dramatizaci románu Berty von Suttner v císařském Německu. Pražský profesor germanistiky, koeditor svazku Milan Tvrdík, známý jako znalec pražské německé a česko-německé literatury, studuje autorčinu českou linii jejího původu a další hlubší souvislosti, Werner Wintersteiner, odborník na otázky míru a mírového hnutí, ukazuje činnost Berthy von Suttner v rámci rakouského mírového hnutí, které mělo zabránit světové válce.

Každý přispěvatel je v podstatě $\mathrm{z}$ jiného oboru, používá jinou metodologii, je zde však patrný i komplexní př́ístup a skutečná interdisciplinarita, i když není taková, jak kniha slibuje. Není v silách jediného recenzenta zodpovědně tyto příspěvky v úplnosti a detailně zhodnotit, na to má znalosti jen málokdo, nebot' nejde jen osobnost nositelky Nobelovy ceny za mír, ale také celého dobového kontextu a také jejího zhodnocení z pozice současnosti. Nicméně lze říci, že jde o velmi dobrý a užitečný projekt již tím, že jsou v něm zapojeni lidé nejen různých oborů, ale také $\mathrm{z}$ různých zemí, s rozsáhlými znalostmi a zkušenostmi, filologové a sociální vědci, specialisté. V této etapě je výstup svazku vynikající, ale v dalším postupu by bylo zajímavější, kdyby se úsilí spoluautorů spojilo do nějaké celistvější koncepce, která by nahlížela autorčin život, dílo a aktivity z pozice celistvější metodologie, což jistě není snadné, ale intelektuální potenciál tomuto kolektivu nechybí. Některé studie už mají přesahy, jež je vymaňují z úzkého záběru - ke Komenskému, k mírovému hnutí, k dobové filozofii, sporům pohlaví a ženské otázce, ovšem také $\mathrm{k}$ př́íčinám Velké války a $\mathrm{k}$ prapříčině toho, že všechny tyto mírové aktivity právě v německy mluvících zemích fakticky selhaly. K dílčím výsledkům lze mít kritické připomínky; Například k žánrové charakteristice jejího stěžejního románu Odzbrojte!, k filozofickým souvislostem, resp. k absenci některých myšlenkových proudů, s nimiž dílo Berthy von Suttner souviselo, k poetice její novelistiky apod. Autorčin pobyt v Gruzii, tedy na území 
tehdejší Ruské říše, by mohlo vést $\mathrm{k}$ dalším souvislostem její tvorby a nejde jen o Rusko, ale také o USA a jejich problémy. K Rusku se kdysi vyjádřil již ruský badatel působící v Německu Valentin Belenčikov (Belentschikow) v knize Bertha von Suttner und Russland (Lang, Frankfurt am Main 2012) právě v řadě Vergleichende Studien zu den slavischen Sprachen und Literatur. To ukazuje na několik jen málo využitých sfér v tomto bádání: literární komparatistika, genologie a areálová studia. A samozřejmě to upozorňuje, zejména $\mathrm{v}$ některých příspěvcích, na důležitost zkoumání autorčina kultu, tedy toho, čím ji společnost nebo společnosti uctívají a jaké emblémy jsou s jejím jménem, životem a dílem spojovány - to je dnes disciplína módní a je spojena i s medializací. V devadesátých letech 20. století a v době těsně následující se konala řada konferencí a sympozií; publikovaly se studie a knihy v německy hovořících zemích a v České republice. Nyní je to třeba mediálně zhodnotit z pozice jejího současného významu, nebot' - stejně jako za jejího života, zvláště od počátku 20. století - je i toto období dobou válečných příprav - v co vyústí, není známo. Nejen zkoumání uměleckých směrů, jež její dílo zasáhly, ale také analýza určité pacifistické naivity, která je tu patrná, bude jistě předmětem seriózního výzkumu, stejně jako její traktování ženské otázky a hledání nových poloh v souvislosti s radikálním feminismem. Tím se postava Berthy von Suttner, stejně jako řady i zde zkoumaných osobností, stává nanejvýš aktuální. Tyto připomínky nejenže nesnižují v podstatě průkopnický ráz této publikace, na níž je pozoruhodná interdisciplinarita a internacionální spolupráce evropské dimenze, ale naopak ukazují na fakt, že publikace otvírá v suttnerovském germanisticko-slavistickém, obecně filologickém a sociálně vědním bádání nový prostor.

\section{prof. PhDr. Ivo Pospíšil, DrSc.}

Ústav slavistiky

Filozofická fakulta, Masarykova univerzita

Arna Nováka 1, 60200 Brno, Česká republika

ivo.pospisil@phil.muni.cz 